\title{
NEW PARADIGMS OF UNDERSTANDING A CHILD, QUALITY OF CHILDHOOD AND CHILDHOOD INSTITUTIONALIZATION
}

\author{
Dr. Anka Jurčević Lozančić, Associate Professor \\ University of Zagreb, Faculty of Teacher Education, Zagreb, Croatia
}

\begin{abstract}
:
According to the contemporary understanding, a child is an integral being, an active participant in his/her own education, a curious and competent being with diverse interests, capabilities, knowledge and understanding, and a person who, driven by an innate curiosity, explores the world surrounding him/her, and actively acquires knowledge. These new paradigms have influenced the revision of understanding a child and his/her childhood, which is not only a preparatory stage for the future, but the period of life that has its own values and culture. Childhood is a process that is contextualized, always in relation to a specific space, time and culture, and varies according to different conditions and cultures in which it occurs. And it is the status of a child, conceived by adults, that is reflected in the overall education of the child, thus becoming a decisive factor in determining his/her social and ethical identity. This paper discusses the basic attitudes relating to a child and his/her childhood, upbringing, development and education within family and institutional surroundings.
\end{abstract}

Keywords: child, modern childhood, family, childhood institutionalization

\section{INTRODUCTION}

Contemporary theoretical approaches, together with empirical research in pedagogy, sociology, psychology, anthropology, ethnography, and other related sciences, interpret childhood as a social construct (Woodhead, 2012) differently understood in different cultures, also discussing the plurality of childhood (James \& James, 2004; Prout, 2005; Babić, 2014). The possible reasons for the pluralities of childhood, which are becoming more and more frequent, Corsaro (2005); Prout (2005); Fass (2006) find in economic and cultural globalization, growing inequality, changes in modern families and different demographic trends. Therefore, due to the diversity of childhood, we can talk about a pedagogic reconstruction of childhood which is not a unique phenomenon, but a complex sum of different relationships and influences. Woodhead (2012) defines childhood as a sociocultural phenomenon, i.e. a social structure that interacts with other structures, values, and ideologies of a society. A child, by actively participating in certain activities (practicing), adjusts to certain structures and actively changes and upgrades them. The viewpoint that many theoreticians have in common is recognized in focusing on a child who, in interaction with a particular environment, realizes his/her potential. The knowledge that is thereat generated results from the child's interactions with the natural world in a certain sociocultural context, with the dynamic mediation of his/her previous knowledge (Bruner, 2000). For the modern image of a child, it is decisive that, during the first years of his/her life, a child acquires preeminent knowledge and models from his/her environment, and that sociocultural processes of understanding determine ways and patterns of how the child interacts with his/her environment. The sociology of childhood and the new paradigm on childhood emphasize changes in the understanding of childhood; the child is not an object or 
a passive recipient of adult care and protection (Corsaro, 2005), but a social and cultural being (Pen, 2008) that actively contributes to its personal development. In other words, we can talk about a child as a being of social relationships, or a child in social relationships (Quortrup, 2005; James \& James, 2008), or children in globalized society, culture, and the world (Fass, 2006). In this sense, Babić (2014) considers theoretical contemplations and findings of empirical research on the reality of childhood in the globalized world, placing them in the context of the changes that modern childhood is undergoing today. The modern childhood today is a research field for numerous authors to whom the issues of child development and education are a part of their scientific orientation. Critically elaborating the question of methods and ethics of research, Babić (2014) talks about the application of methodological procedures based on the process of childhood measurement and standardization in order to obtain reliable numerical data. Instead of measuring and standardizing, the approaches in the methodology of modern research paradigm put the emphasis: "on the research with instead of on children, wanting to put the children in the position of social actors who are subjects, and not objects of research. A change in the direction of research, from research on to research with the children, became a general trend" (Corsaro, 2005, as cited in Babić, 2014, p. 68). The research and contemporary theoretical frameworks in the area of childhood point to approaches that deal with studying the practice in the daily life of a child and explore the children's attitudes, relationships, and activities within which the early years of a child are constructed. Focus is on the research with children in which the children are subjects of research, i.e. social actors who have their voices, perspectives, and interests. From the perspective of contemporary sociological theories, some of the general methodological questions do not arise solely from methodological approaches, but they are already ensuing in the personal and professional understanding and interpretation of childhood (Marković, 2008). In this sense, the author speaks of the continuous need to question and problematize research reflections and their meanings, as a tool that will help better understand and improve childhood. Dahlberg, Moss, and Pence (2003) deliberate about the institutional development of early education in the context of changed conditions in the family, which, among other things, have conditioned the process of childhood institutionalization. Due to the above-mentioned circumstances, children are coming to early education institutions earlier and earlier, which justifies the growing need for their observation and monitoring of the educational process quality.

\section{A PARADIGM IN THE CONTEXT OF CHANGES THAT OCCUR WITH REGARD TO A CHILD}

Many children nowadays spend most of their time in institutional care in specially designed and organized environments that segregate children according to their age and abilities, and which are frequently controlled by different adults. Institutions where children spend their time growing up - for example, early education institutions, sports and other clubs - are in a correlational relationship with economic and cultural resources of the family (Shaw and Wood, 2009). The general attitude of the adults that, if a child does not aspire to what is best for him/her, he/she will not have a quality life in the future, is conditioned by the consumer culture that strives for success and material wealth, and is nurtured since childhood, Honoré (2009) emphasizes, describing and defining modern parenting and childhood in terms of hyper-parenting and the period of a managed child. Corsaro (2005), referring to the changes in the modern society that affect childhood, specifically sets out different ways of life within the family, such as more frequent employment of mothers, more common occurrence of divorce, increasing family income with simultaneous growth of life costs. Considering the author's views, it can be concluded that the influence of consumer culture in all areas of life is such that the child is lost from culture as a human, active subject, and becomes a consumer 
and an object of the cultural offer. Furthermore, Corsaro (2005) warns of discontinuity between the family values and organization of the institution and of the increasingly frequent problems of modern childhood and its institutionalization. Even though this is often pointed out in the relevant literature, it is important to emphasize that the intense institutional colonization is fragmenting the world of a child, conditions the childhood crisis (Prout, 2005), and serves its disappearance (Postman, 1994), or its changes, because the period of growing up is full of rules and classifications deeply rooted in the need for professional and social control (Qvortup, 2005). Since the daily life of a child takes place in the spatially-and time-controlled activities of the child, the significance of his/her social and communication competence, as well as the importance of the play and the complexity of the playing process, are diminished. The play, placed in the sphere of adult culture, becomes a training polygon whose goal is to learn by playing and is often rewarded with something external as a substitute for original pleasure (Bašić, 2011). Similarly, Babić and Irović (2003) point out that the play characterized by intrinsic motivation and expressiveness, symbolism and self-regulation does not fit into the context of institutional education and is therefore isolated and suppressed beyond educational programs. According to the above-mentioned, it is possible to notice a few trends of development that indicate the shortening of childhood and are recognized in the shorter time that the child spends in the free play and in the increased demands of the parents and the society for the institutional acquisition of competences (Bašić, 2011). It is in this confiscation of the child's freedom, voluntariness, and joy during the spontaneous play that we can recognize its disappearance. Modern childhood has become predestined for various external influences, and here we can talk about a consumer child, or the commercialization and childhood manipulation. In her impressive essays, the author Fass (2006) speaks of the children of the new world, and gives an insight into the position of children in the modern society, which is characterized by numerous tensions and contradictions. On the one hand, there is a problem in reducing the quality of childhood despite the fact that modern science pays great attention to early childhood development and education, its possibilities and the provision of better quality conditions for growing up. On the other, reducing the boundaries between childhood and adulthood is one of the symptoms of childhood disappearance. This boundary is gradually lost under the influence of increasingly pronounced media dominance, frequency and availability of content that is not appropriate for children, which causes a reduction in the duration of childhood that slowly disappears (Prout, 2005; Fass, 2006; Marković, 2008). Or more specifically: "Today, children do not live only within the framework of a society or family with whom they share their daily lives and necessary tasks. They are a part of the global world based on the division of work, they live according to a schedule and pre-defined terms, in the world of fast changes and a hurried pace which is not in line with their strengths and physical and moral problem solving" (Flitner, 2005 p. 121). The author compares the rule of polis with the position of a child in the modern society, claiming that the children do not get enough opportunities for dialogue and (co)deciding. Shaw and Wood (2009) share similar views, discussing the hurried childhood as a symbol of modern way of life that leaves little time for a child to relax and reveal his/her personal identity. New concepts, as an alternative approach to childhood, are based on the assumption that the child as a social being has a constant need to accomplish different interpersonal relationships, trying to overcome the boundaries and barriers imposed by the adults (Corsaro, 2005) in order to continually expand his/her existing understanding of the world. Problematizing the features of the modern image of the child from a pedagogical perspective, Rinaldi (2006); Slunjski (2008); Miljak (2009); Bašić (2011); Vujičić (2011); Babić (2014) talk about a child as a subject of his/her own development that is, in his/her individual and biographically unique way, involved in the social context. Thus, instead of a traditional model or an approach based on a model and authority, the importance of modern pedagogical relationship based on the self-realization and autonomy (freedom and responsibility) of a child is emphasized. Therefore, the recent contemporary literature that has been written during the last ten years often emphasizes the importance of relationships or the pedagogy of relationships that 
are the starting point and the drivers of the overall development of the child. The pedagogy of relationships is a dynamic, complex network of connections and feedback, initiated by actions and interactions between the child and the environment, which is the foundation for successful learning and well-being of the child. Theoretical starting points of the approach focused on relationships are based on the essential items of social constructivism, sociology of childhood, postmodernism, and poststructuralism (Dahlberg et al., 2003). What all these concepts have in common is the approach to education as a complex system that does not change on the basis of universal and objective laws and truths, but merges different patterns and ways of acting and thinking. According to poststructuralist views, there is a multitude of realities and interpretations of reality that are built by discourse and by supporting the development of fundamental humane democratic values, such as the culture of dialogue, acceptance, and giving. In a number of professional and scientific publications, the interpretation of the child as a competent being with an authentic way of learning and expressing themselves, observed through the prism of social constructivism as the theoretical foundation of childhood is emphasized (L. Vygotski, as cited in Wood \& Attfield, 2006). These points of view gain special significance within the framework of a new paradigm of development in which the development is inseparable from the social context in which it takes place, since everything a child learns and the way he/she learns is a significant part of the cultural curriculum of a particular society. This implies that the development of an individual is the product of his culture and is therefore called a sociocultural approach. Consequently, the outlook on the social context in which the development and education is realized has to change, and the main question is that of creating an optimum environment for learning and education in family and institutional conditions. For these reasons, Bašić (2011) suggests some viewpoints that can contribute to a better understanding of the pedagogical concept of education and the quality of childhood, which, according to the author, means constantly questioning not only what a child can do, but also how or with what we can awaken his/her potentials, interests, emotions. The deciding factor for the contemporary understanding of a child is understanding and seeking answers to questions, which makes sense for the child and empowers him/her in dealing with himself/herself, the others and the world at certain moments of his development. An educational institution should be seen as a community in which humane forms of human coexistence, equal participation and mutual learning of children and adults are developed (Babić \& Irović, 2003). From the perspective of contemporary pedagogical theory, social experience, current social relationships and general impacts to which the adults and children are exposed, affect their value orientation and behaviour. In the contemporary pedagogical approach, childhood is recognized as a "structural form, and children as social actors who contribute to the reproduction of childhood and society through negotiation with adults and creative production of series of peer cultures with other children" (Babić, 2014, p. 22). These new concepts ultimately create new paradigms of early and pre-school education that encompass ideas about the necessity of changing the relationship between adults and children. The adults and the children are in constant interrelationship; the adults from the perspective of authority, and the child, acting on its own, actively affects others in his/her surroundings (the adults and the children), with whom he/she is in different relationship (within the family or institution). There are numerous articles and books that, in detail, elaborate the play as a unique childhood phenomenon; the play reflects the child's current development zone, but it is also the area of the succeeding development for many mental functions (Duran, 2003). According to the aforementioned author, the play is an expressive, autotelic, independent, divergent activity in which, unlike other practical routines in childhood, the adults give the child maximum independence, and in it, the zone of current development, the zone of creative independence, and the zone of free movement are subtly opened. That is why in early childhood it is extremely important to provide the child with conditions for independent discovery and learning based on the play and other activities that are interesting to the child, as well as to create institutional conditions for healthy growing up. 


\section{ECHOES OF PLAY IN THE PROCESS OF GROWING UP}

In recent literature, for example Duran (2003); Penn (2008); Marković (2008); Babić (2014), individual experiences of everyday life are associated with the sense of nostalgia in correlation with the play and childhood. The time of childhood that can never be repeated is marked by memories. According to Marković (2012), childhood memories are a (re)interpretation of the past in the present, and childhood without play would be no childhood at all. "In the end, children are all around us, a child lives in us and in our autobiographical memory, in our knowledge and memories of our own past (...) Withdrawal into the area of the childhood that is behind us and the isolated and protected world dominated by togetherness in play is actually an escape from the changes brought by the present. Or more concretely, memories of childhood are interwoven with our everyday lives, and because they are hidden, they become a treasure trove of information, knowledge, and the notions of the past times, customs, and ways of life (Marković, 2012). In addition, memories of childhood imply significant connections and interaction between people, experiences of sharing, togetherness, and accepting each other, and games and toys, as credible signs of childhood, become childhood legacy, a reminder of the available means that make children feel safe and offer a way for them to build their own imaginative words (Duran, 2003). All of these are subjective reasons needed for the memories to be confirmed and renewed through the preserved images of childhood that the adult person keeps deep inside as their belief. The play seen with reflexive nostalgia becomes idealized and embellished, reminder of the (re)constructed time of spontaneity and carelessness so for example... play in nature implies adventures in the memories... reminding us of movie and literary heroes and scenarios full of freedom and excitement... (Duran, 2003). There are numerous examples in life that confirm that smaller towns or places of residence may still be gravitating towards spending time in nature, but urban areas are in constant pursuit of protecting young children and their growing up, and mostly offer various children's facilities and parks for play. Space for a free and spontaneous play is disappearing from the culture of a modern child, being replaced by indoor and other specialized spaces. The play that takes place in the presence of adults on the playground of a nearby park takes spontaneity from children and restricts them... because it is not advisable to climb so fast... or to climb together at the same time... thus building their sensitivity and insecurity. It is well known that the play emerges from the sole joy of playing, and everything else that is on the outside wants to determine, restrict, and diminish its creativity and freedom. It is the freedom of the play that implies its productive synergy, creativity, understanding, and testing of different roles, and triggers the child's energy and desire for adventures (Smith, 2009). The originality of the play results from the intertwining of what is real and what is fictive, e.g. whenever a child experiences and amuses himself/herself with the play, he/she feels as if it were reality, knowing at the same time it is only a temporarily transformed fictional world. After all, the play is an extremely important aspect of child development; while playing, the child reinterprets his/her experience and expands his/her personal interests by questioning or exploring the world that surrounds him/her (Pramling \& Fleer, 2009; Jurčević Lozančić, 2014). However, the play is not only a means of discovering the world, but it also represents the joy of socialization and interaction between a child and other children, friends, dolls, or fantasy figures. Togetherness and the feeling of autonomy are developed together and support each other. Therefore, the role of the adults is to encourage and create the conditions for children to play. If we, as adults, can understand the nature and the value of play, and if the personal theories of play and personal practices of play are revised, the adults can be real playmates and promoters of the child's play (Babić, 2014). Moreover, play is the source of every creativity and inventiveness, it is recognized in creative living and the overall context of human life, and is not, as emphasized by Winnicott (2004), reserved only for the childhood period - it is present in all segments of human life. The importance of a certain event 
that is worth remembering in the life of an individual actually belongs to the autobiographical memory and can be considered a segment of one's life story.

In addition to the abovementioned, memories of childhood are generated by emotionally important stories, marked by permanent destruction of time categories, as well as hidden pictures of self, family, society and culture. So, for example, in the book: „Pričanja o djetinjstvu: život priča u svakodnevnoj komunikaciji [Stories about childhood: Life of the stories in everyday communication] "(2012) Jelena Marković explores the issue of talking about childhood and its everyday life, on the basis of testimonies collected from personal memories and the memories of others about the mentioned period. Children's stories, stories about childhood and stories told to children about a past event are formed through different narrative practices. The author professionally affirms her attitude towards the narrative as a practice and activity, rather than a form. Consequently, personal experience of childhood has proved to be an inspirational source of narrative memories with, of course, a nostalgic undertone of the author of this work in an attempt to recall the experience of her own childhood. .... Although many springs have passed since my generation and I were children, I still get overwhelmed by many pleasant memories of my childhood... And suddenly, beloved faces of my first friends appear before me, I can hear the whisper of the first secret in my ear, my heart starts beating with the rhythm of play; everything there is mine... all sounds, smells, all colours and touches of childhood, joyful childhood and growing up.

\section{Final CONSIDERATIONS}

In pedagogical discourses on childhood, a picture of a competent child who is eager to face the world is emphasized. This is the child who wants to grow, learn, know, and create his/her knowledge. The child with an immanent power with a hundred tongues, the being with rich potentials and natural strategies for learning and exploring (Malaguzzi, 1998). In the abovementioned construct of a rich child, learning is a collaborative and communicative activity in which a child shapes his/her knowledge, gives meaning to the world together with other children and adults. These are the earliest active and discovering forms of learning in children based on his/her independent research, discovery, and solving various problem situations, as well as cooperation of the child with other children and adults. Although many books, studies, and professionally popular articles on the child and childhood have been published over the last few decades, it can be argued that, even though quality assurance and monitoring systems depend on the context in which they occurred and exist, it is possible to notice a few common links. The starting point for almost all models of quality assurance and monitoring is the wellbeing of the child. Education and development of the child are inseparable from the social context in which they take place, since learning, as well as the way the child learns, is a significant part of the cultural context of a particular society or community. Quality measurements are based on the contemporary understanding of the child and childhood; they are not preprescribed and unchangeable, but are culturally conditioned, and as such must be illuminated (Woodhead, 2012). Moreover, the question of quality needs to be considered as fundamental, philosophical, and ethical issues that imply the overall values and meanings that are given to the child and childhood. 


\section{Bibliography}

Babić, N. (2014). Suvremeno djetinjstvo: teorijski pristupi, prakse i istraživanja. Osijek: Filozofski fakultet u Osijeku.

Babić, N., Irović, S. (2003). Dijete i djetinjstvo u pedagogijskoj teoriji i edukacijskoj praksi. In: N. Babić, S. Irović (eds.), Dijete i djetinjstvo: teorija i praksa predškolskog odgoja (pp.13-34). Osijek: Sveučilište J. J. Strossmayera, Visoka učiteljska škola.

Bašić, S. (2011). (Nova) slika djeteta u pedagogiji djetinjstva. U D. Maleš (ed.) Nove paradigme ranoga odgoja (pp.19-37). Zagreb: Filozofski fakultet Sveučilišta u Zagrebu, Zavod za pedagogiju.

Bilić, V., Bašić, S. (2016). Odnosi u školi: prilozi za pedagogiju odnosa, Zagreb: Učiteljski fakultet Sveučilišta u Zagrebu.

Bruner, J. (2000). Kultura obrazovanja. Zagreb: Educa.

Corsaro, W. A. (2005). The Sociology of Childhood. Thousand Oaks, CA: Pine Forge Press.

Dahlberg, G., Moss, P., Pence, A. (2003). Beyond Quality in Early Childhood Education and Care. Postmodern perspectives. Philadelphia: Farmer.

Duran, M. (2003). Dijete i igra. Jastrebarsko: Naklada Slap.

Fass, P. S. (2006). Children of a New World: Culture, Society, and Globalization. New York: University Press.

Flitner, A. (2005). Kondrade, tako je govorila gospođa mama - O odgoju i ne-odgoju. Zagreb: Educa. Honoré, C. (2009). Pod pritiskom. Spašavanje djece od kulture hiperroditeljstva. Zagreb: Algoritam.

James, A., James, A. (2004). Constructing childhood: theory, policy and social practice. London: Palgrave Macmillan.

James, A., James, A. (2008). Key Concepts in Childhood Studies. London: Sage Publication.

Jurčević Lozančić, A. (2014). Pedagogical Aspects of Socializing Processes in Children's Play. Croatian Journal of Education, $16 \mathrm{Sp}$.Ed.(1), 81-93.

Jurčević-Lozančić, A. (2017). Socijalne kompetencije u ranome djetinjstvu. Zagreb: Učiteljski fakultet Sveučilišta u Zagrebu.

Mallaguzzi, L. (1998). History, Ideas and Basic Philosphy - AnInterview with Lella Gandini. (in): Edwards, C.P., Gandini, L., Forman, G. (eds): The Hundred Languages of Children - The Reggio Emilia Approach, Advanced Reflektions. London:Ablex Publishing Corporation, pp. 49-97.

Marković, J. (2008). Je li etično etički istraživati s djecom? Neka etička pitanja u istraživanju folklorističkih i kulturnoantropoloških aspekata djetinjstva. Etnološka tribina. 32 (pp.147-165).

Marković, J. (2012). Pričanja o djetinjstvu. Život priča u svakodnevnoj komunikaciji. Zagreb: Nova etnografija.

Miljak, A. (2009). Življenje djece u vrtiću. Zagreb: SM Naklada.

Penn, H. (2008). Understanding early education, Issues and controversies. Berkshire: Open Univerity Press.

Postman, N. (1994). The disappearance of childhood. New York: Vintage/ Random house.

Pramling, S., Fleer, M. (2009). Play and learning in early childhood settings - international perspectives. London: Springer.

Prout, A. (2005). The Future Of Childhood. Toward The Interdisciplinary Study Of Childhood. London. New York: RoutledgeFalmer.

Qvortup, J. (Ed.) (2005). Studies in Modern Childhood. London: Palgrave Macmillan.

Rinaldi, C. ( 2006). In Dialogue with Reggio Emilia. London. New York: Routledge, Taylor \& Francis Group.

Shaw, R., Wood, S. (2009). Epidemija popustljivog odgoja: zašto su djeca nevesela, nezadovoljna, sebična te kako im pomoći. Zagreb: V.B.Z.

Slunjski, E. (2008). Dječji vrtić: mjesto dijaloga, suradnje i zajedničkog učenja. Zagreb: Spektar media. Smith, P. (2009). Children and Play Understanding Children's Worlds. Oxford: Wiley-Blackwell. Vujičić, L. (2011). Istraživanje kulture odgojno-obrazovne ustanove. Zagreb: Mali profesor. Winnicott, D.W. (2004). Igra i stvarnost. Zagreb: Prosvjeta, 
Wood, E., Attfield, J. (2006). Play, Learning and the Early Childhood Curriculum. London: Paul Chapman Publishing.

Woodhead, M. (2012). Različite perspektive o ranom detinjstvu : teorija, istraživanje, politika. Beograd: Filozofski fakultet, Univerzitet u Beogradu.

\section{Nove paradigme shvaćanja djeteta, kvalitete djetinjstva i kvalitete institucionalizacije djetinjstva}

Sažetak: Prema suvremenom shvaćanju dijete je cjelovito biće, ono je aktivni subjekt vlastitoga odgoja i obrazovanja, znatiželjno je i kompetentno biće koje ima raznovrsne interese, mogućnosti, znanja, razumijevanja i koje, vođeno prirođenom znatiželjom, istražuje svijet oko sebe i aktivno stječe znanja. Te nove paradigme utjecale su na izmjenu shvaćanja djeteta i njegovoga djetinjstva koje nije samo pripremna faza za budući život već je životno razdoblje koje ima svoje vrijednosti i kulturu. Djetinjstvo je proces koji se kontekstualizira i uvijek je u relaciji s određenim prostorom, vremenom i kulturom te se razlikuje s obzirom na različitost uvjeta i kulture u kojima se ostvaruje. Upravo položaj djeteta, koji su osmislili odrasli, odražava se na cjelokupni odgoj i obrazovanje djeteta, te postaje odlučujući činitelj u određivanju njegovog društvenog i etičkog identiteta. $U$ ovom radu problematiziraju se temeljna stajališta o djetetu $i$ njegovom djetinjstvu, odgoju, razvoju i obrazovanju u obiteljskom i institucionalnom okruženju.

Ključne riječi: dijete, suvremeno djetinjstvo, obitelj, institucionalizacija djetinjstva

\section{Neue Paradigmen im Verständnis des Kindes, der Qualität von Kindheit und Institutionalisierung von Kindheit}

Zusammenfassung: Laut gegenwärtigem Verständnis ist das Kind ein ganzheitliches Wesen, aktives Subjekt in seiner eigenen Bildung, ein neugieriges und kompetentes Individuum mit diversen Interessen, Fähigkeiten, Kenntnissen und Erkenntnissen, das von seiner natürlichen Neugierde getrieben die eigene Umwelt erforscht und aktiv Kenntnisse erwirbt. Diese neuen Paradigmen haben einen Wandel im Verständnis des Kindes und seiner Kindheit beeinflusst, wonach Kindheit nicht mehr lediglich eine Vorbereitungsphase auf das zukünftige Leben darstellt, sondern eine Lebensperiode mit eigenen Werten und eigener Kultur. Die Kindheit ist ein Prozess, der immer in Beziehung zu einem bestimmten Raum, Zeit und Kultur steht und sich in Bezug zu den unterschiedlichen Bedingungen und Kulturen, in denen er sich vollzieht, unterscheidet. Gerade der Status des Kindes, der seitens Erwachsener definiert wird, spiegelt sich in der gesamten Erziehung und Bildung des Kindes und wird zum entscheidenden Faktor der Bestimmung seiner gesellschaftlichen und ethischen Identität. Diese Arbeit problematisiert die grundlegenden Standpunkte über das Kind, die Kindheit, Erziehung, Entwicklung und Bildung in der familiären und institutionalisierten Umgebung.

Schlüsselwörter: Kind, zeitgemäße Kindheit, Familie, Institutionalisierung von Kindheit 